\title{
Students, interns in protest about examinations
}

Do not arrange to be sick in France just now. Medical students, interns and heads of clinics in teaching hospitals are all on strike. Professors are taking over the more menial duties of patient care, and patients are turning to private medicine. (The massive French social security system pays back up to 80 per cent of the fees.) The overt issues are new examinations (for the student) and security of employment (for the interns and clinic chiefs). But a general malaise of the medical system and uncertainty about the future may be the true cause.

The students have been on strike since 22 March, and last week their action boiled over into demonstrations in many major towns: roads were blocked and signs were daubed in Nice, barricades were burned in Marseilles, paving stones torn up in Bordeaux and the riot police were out in Paris.

The scenes evoked memories of 1968 , when all the universities took part in demonstrations on the streets. And 1968 plays a part in the present troubles. After the "revolution", examinations were softened, spread out into frequent assessments along a six-year course with no final examination. Now the Socialist government, in a reform whose origins date back to the previous administration of Giscard d'Estaing, wants to re-establish a system of final examinations covering all the work of the course.

In fact the government wants two examinations, the first general and the second, to be taken three months later, covering a specialist field of the student's choice. But the real crunch is that the first examinations would be set next year, so a large number of students now well into their studies based on continuous assessment would be forced to face a further, and unexpected, hurdle. Hence the riots. The government, meanwhile, stands firm and offers no compromise although professors quietly expect that there will be one that takes the form of delay, so that the examinations will not affect the existing student body, but will be phased in with all future intakes. The general feeling seems to be that it is reasonable to have an examination but unreasonable to impose it quite so suddenly.

As for the interns and chefs de clinique, their problems are different. They are complaining about their salaries and job insecurity. To become an intern at a teaching hospital (of which there are 13 in Paris, and often two in other major cities) is about as difficult as joining one of the grandes écoles and is similarly considered to be a privilege. The job, like its equivalents in other countries, is a fouryear mixture of training and patient care. The pay is appropriate to a student, but too little for the responsibities of the job and the age of the incumbents, say the interns.

Moreover, as elsewhere, internship and the following post of chef de clinique are not careers: at the end of four years, an intern can move on to be chef de clinique, again a four-year post, after which the student must pass an examination to become an assistant professor (a permanent post) at the teaching hospital, or move out into private practice. But private medicine has been contracting in France for some years, and the interns want new guarantees of employment: they demand either that internship (or the chef de clinique) be considered permanent posts, or that the number of assistant professorships awarded each year be increased (it was 85 last year, and the interns seek 500) or that they have an exclusive route out into the public nonteaching hospital parallels of assistant professorship. At present, those jobs are filled in part from teaching hospital interns and in part from elsewhere: the teaching hospital interns demand exclusive and contractual rights to be considered first for these jobs.

Again, as with the students, the government appears to be inflexible. The previous, Communist minister of health, Jack Ralite, fell in the recent reshuffle to be replaced by Socialist Edmund Hervé (exjunior minister of energy) and everyone is waiting to see where his sympathies lie; but meanwhile, the government appears to have shifted the problem onto the minister of social services, Pierre Bérégovoy, who has a widespread reputation as a troubleshooter.

He may succeed in this instance - but at root the French troubles may lie deeper than even Bévégovoy can reach. Despite the shrinking private sector, a working public health system is still not properly established in France, many in the present government feel.

Meanwhile, as with all national health systems, costs burgeon and government thoughts, particularly a Socialist government's thoughts, turn to radical reform. In the medical community, therefore, insecurity reigns, and the strikes are a symptom of it.

Robert Walgate

\section{French research \\ Fabius promises no change}

RESEARCH is safe with Laurent Fabius! That, at least, is how the new minister of industry and research in France declared himself last Monday. On his own recognisance, $\mathbf{M}$. Fabius fully supports the ambitious initiatives of his predecessor, Jean-Pierre Chevènement.

Making his first major speech in his new post (he was previously the budget minister, holding Chevènement's pursestrings among others), Fabius declared that he "supported every promise" of the law for science passed by the French Parliament last year. He supported the "programmes mobilisateurs", (the seven areas of special support singled out by Chevènement), the principle of opening science to industry and generally breaking down barriers to communication and cooperation and the goal of raising total French civil research and development spending to 2.5 per cent of the gross national product by 1985 . Despite the cost, this was "an indispensable effort", he said.

Earlier, Fabius had announced through the French press agency (AFP) that he now felt himself "a spokesman for the future", - obviously relishing his new position "I know that the scientific community is now mobilized and prepared to make research a national priority. I feel today and it is a great responsibility - the inheritor of this trust."
Thus in many quarters of French science there must be a feeling now that $\mathrm{M}$. Fabius may not prove to be the scourge that had been feared. Nevertheless, the details of the revised French budget for 1983 , taking into account new austerity measures, have yet to be announced, and pessimists point out that Fabius has committed himself only to 2.5 per cent by 1985 .

Earlier this year, before the reshuffle, the Centre National de la Recherche Scientifique (which supports most basic research) announced a supposedly temporary spending freeze, limiting spending to 60 per cent of previously agreed figures; and the medical research council INSERM more optimistically restricted itself to 80 per cent. These restrictions stil stand, and if confirmed would certainly eliminate the increases achieved under the previous minister. Thus a meeting of the council of INSERM this week to discuss budgets is described by one director of a major laboratory as "of prime importance for my laboratory's survival in 1984'”.

French scientists are now waiting impatiently to see what the rhetoric of $\mathbf{M}$. Fabius looks like when it come to hard francs. M. Chevènement's example is awesome, both for its new minister and for the government of which he was a part.

Isabelle Trocheris 